\title{
THE ASSOCIATION BETWEEN CORPORATE GOVERNANCE AND COMPANY SHARE REPURCHASES: EVIDENCE FROM TAIWANESE SMALL AND MID-SIZED COMPANIES
}

\author{
${ }^{1}$ WANG CHIEN JEN, ${ }^{2}$ YU HSUAN PEI \\ ${ }^{1}$ Associate professor of International Trade Dept., \\ Takming University of Science and Technology, Taiwan. \\ ${ }^{2}$ International Trade Dept., Takming \\ University of Science and Technology, Taiwan.
}

DOI: 10.46609/IJSSER.2020.v05i04.001 URL: https://doi.org/10.46609/IJSSER.2020.v05i04.001

\begin{abstract}
This study uses Taiwan's small and mid-sized companies under NTD 10 billion market capitalization to explore the impact of when a company first implements a strategy of share repurchase. In the empirical results of this study, we can see that company stock prices go up right after the announcement of share repurchase. Before the announcement of share repurchase, the company debt ratio indicates the agency costs have a significantly negative effect on company abnormal returns. After the announcement, we can observe that corporate governance factors - directors' ownership and foreign institutions' ownership - are more significant than before the announcement, both having a significantly positive effect on company's abnormal returns. This illustrates that a good corporate governance system possesses monitoring effects on a company's performance. Meanwhile, the company's share prices, current ratio and post operating performance go up after the announcement. Frequent share repurchases often correlate with the signal of poor operating performance. This situation may be improved with a good corporate governance mechanism.
\end{abstract}

Keywords: Abnormal returns, Corporate governance, Directors' ownership, Share repurchase, Small and mid-sized companies

\section{INTRODUCTION}

Presently, a company's financial managers adopt multiple strategies to raise a company's share prices or improve operating performance. Share repurchasing is an important strategy that 
International Journal of Social Science and Economic Research

ISSN: $2455-8834$

Volume: 05, Issue: 04 "April 2020"

managers must consider in this effort. However, the motivation of managers behind share repurchase policy and the short-term and long-term impacts of share repurchase on a company's performance still need to be explored and studied with multi-faceted empirical studies if we are to fully understand the implications of this particular strategy. The issue of company share repurchase has been gradually garnering more interest internationally, as many questions remain to be answered. For example, how does the timing of a share repurchase policy affect cumulative abnormal returns? What is the short-term and long-term impact after the announcement of share repurchase? Is the impact on share price only a short-term phenomenon, with any price increase fading away? In addition, is the motivation of top management to genuinely adjust company capital structure or only to adopt share repurchase policy after facing company undervaluation? The above issues all need multifaceted empirical researches to gain a clearer understanding.

A share repurchase policy is implemented by purchasing previously issued company shares. The repurchased shares may then be canceled, used for employee incentives, or resold. Financial reporting after performing a share repurchase may decrease the number of shares outstanding while increasing the company's EPS. Owing to the information asymmetry of the market, the information held by company managers and shareholders has obvious differences. Generally, shareholders can only obtain information about capital financing, financial reporting, and dividend policy to determine future development, but managers have more information. Under information asymmetry, managers may use a high dividend policy to express optimism for the company's future performance. Further, poor performing companies may use some strategies such as share repurchase to prevent outside investors from knowing about the company's poor operating performance. This is the signaling hypothesis that is constructed on asymmetric information. Vermaelen (1981) noted that when companies announced share repurchases, it has a positive effect on their share prices. Grullon and Michaely (2004) found evidence that companies that use share repurchases to reduce cash dividends will have lower share prices drops, compared with the companies giving cash dividends only. This seems to indicate that a company performing a share repurchase may create more value for shareholders. According to the signaling hypothesis, share repurchases probably release signals to the market that the company is undervalued. Dittmar (2000) expressed that owing to the information asymmetry between managers and shareholders, there is an incentive for a company to signal undervaluation in the market. While, share repurchases release information to the market, only managers have complete information. Further, Wu (2012) pointed out poor-quality companies probably pretend to be performing well by sending such signals with a share repurchase. Through this process, while their information costs are lower, abusing information asymmetry to intentionally mislead the market is unethical.

Han, Lee and Song (2014) estimated the relationship between share repurchase and company 
International Journal of Social Science and Economic Research

ISSN: $2455-8834$

Volume: 05, Issue: 04 "April 2020"

undervaluation using data from Korean companies, and found that companies that frequently repurchase shares have lower post-announcement operating performance, compared to companies that repurchase shares less frequently. Further, for companies that perform share repurchases frequently, agency costs negatively affect the company's abnormal returns after such an announcement. Han, Lee and Song (2014) also pointed out that while frequent share repurchases probably indicate company undervaluation it also probably produces some benefits right after the announcement, and the company tends to repurchase shares for the following reasons: share price stabilization, management rights stabilization, preparing to pay share options to managers and employees, preventing mergers and acquisitions by another company, and stimulating and increasing share transaction volumes in the market, among others.

Previous studies have explored the comparison of share price reactions of frequent and infrequent share repurchase. Jagannathan and Stephens (2003) discovered that the motivation of companies who repurchase shares frequently differs from those who repurchase shares infrequently. Usually, infrequent share repurchase companies have stronger share price reactions than those of frequent share repurchase companies. Yook (2010) also noted that the degree of company undervaluation positively affected company abnormal returns. That is, in the shortterm, the more a company was undervalued, the more abnormal returns the company could expect. However, in the longer term, frequent share repurchase companies will not exhibit significant positive abnormal returns. This phenomenon implies that the motivation behind the frequent share repurchase company may, in fact, be the company's poor operating performance, not undervaluation. Further, there is some evidence that share repurchase sometimes provides only a short-term benefit, occurring particularly just after the announcement, while in the longerterm, frequent share repurchase probably harms a company's value. Therefore, the share price reaction of share repurchases in different situations can be extensively explored in future research.

Jagannathan and Stephens (2003) showed that companies with infrequent share repurchases had higher insider ownership and better corporate governance than companies with frequent share repurchases. Adding to this finding, Ginglinger and L'her (2006) suggested that the ownership structure can be a corporate governance indicator to decide whether a company needs to perform a share repurchase. Singh and Davidson III (2003) showed that a company's ownership structure significantly affects the degree of a company's agency problem. The firm's poor operating performance is also a kind of agency problem. Ang, Cole and Lin (2000) argued that as the ownership of managers increases, the agency problem will be decreased. This means that stronger corporate governance may mitigate a company's agency costs. We can see that in the sphere of corporate governance, ownership structure and board independence will affect the probability of share repurchase signaling. Good corporate governance may mitigate agency costs 


\section{International Journal of Social Science and Economic Research}

ISSN: $2455-8834$

Volume: 05, Issue: 04 "April 2020"

and thereby decrease company undervaluation. This argument supports and confirms that corporate governance systems possess monitoring effects for the company.

This study uses Taiwan's small and mid-sized companies (under NTD 10 billion market capitalization) to explore the impact of when a company first implements a strategy of share repurchase. In the empirical results of this study, we can see that company stock prices go up right after the announcement of share repurchase. Before the announcement of share repurchase, the company debt ratio indicates the agency costs have a significantly negative effect on company abnormal returns. After the announcement, we can observe that corporate governance factors - directors' ownership and foreign institutions' ownership - are more significant than before the announcement, both having a significantly positive effect on the company's abnormal returns. This illustrates that a good corporate governance system possesses monitoring effects on a company's performance.

The remainder of this paper is organized as follows. Section 2 presents the empirical model. Section 3 presents the methodology and data, while section 4 describes the empirical results. Finally, section 5 concludes.

\section{EMPIRICAL MODEL}

Han, Lee and Song (2014) focused on large Korean companies to examine the relationship between share repurchase, pre-announcement performance, and post-announcement performance, while also considering the effect of corporate governance factors. This study is based on Han, Lee and Song (2014), but with a modified model more suitable for Taiwan's small and mid-sized companies. We adopt the abnormal returns of the company as the dependent variable. Thus, this study examines the association between company abnormal returns $(A R)$, corporate governance, and company financial indicators (current ratio and debt ratio). Six independent variables - corporate governance (director shareholding, foreign institutions shareholding and board size) and company financial indicators (share prices, current ratio and debt ratio) - are considered to perform empirical estimations. Given the relevant variables, the empirical model is formulated as shown in Eq. (1) as follows:

$$
\begin{aligned}
& A R_{i,(t-1, t)}=\alpha_{1}+\beta_{1} B S Z_{i, t}+\beta_{2} F N H D_{i, t}+\beta_{3} \operatorname{DIRHD}_{i, t}+\beta_{4} S T K P_{i, t}+\beta_{5} C R_{i, t} \\
& +\beta_{6} D R_{i, t}+\varepsilon_{i, t}
\end{aligned}
$$

where the dependent variable $-A R_{i,(t-1, t)}$ represents the abnormal returns of company $i$ at period $t$ deduct period (t-1). The independent variables include corporate governance factors and company financial indicators. $B S Z_{i, t}$ represents the number of directors on the board of company 
International Journal of Social Science and Economic Research

ISSN: $2455-8834$

Volume: 05, Issue: 04 "April 2020"

$i$ in quarter $t$. A larger board size indicates that board directors are likely to be much more prudent in business decisions, and their considerations tend to be more consistent with those of the shareholders. $F N H D_{i, t}$ is the number of foreign institutions holding shares of company $i$ in quarter $t$. When foreign institutions own a company's shares, they show concern for the company's operating performance and provide counterviews and objective opinions on the decisions of the directors. An increase in the ownership of foreign institutions can promote monitoring to increase the release of company information to the public and strengthen the quality of monitoring. $D I R H D_{i, t}$ represents the shareholding rate of the directors of company $i$ in quarter $t$. In companies with a higher director shareholding rate, the board typically strengthens its monitoring to reduce information asymmetry.

We also consider company financial variables in the estimation: company share prices, current ratio and debt ratio. $S T K P_{i, t}$ is the share prices of the company. This represents the growth and market value of company $i . C R_{i, t}$ is the current asset ratio of company $i$, measured by company current assets divided by total assets. $D R_{i, t}$ is the debt ratio of the company $i$, measured by company debts divided by total assets; $\varepsilon_{i, t}$ is the disturbance term.

This study employs pooled estimation regression, which combines cross-sectional and longitudinal data. Its methodology includes the fixed-effects model (FEM) and the randomeffects model (REM), as well as the Hausman test to judge the suitability of the models. This method yields reliable coefficient estimates when unobservable individual fixed or random effects exist.

\section{METHODOLOGY AND DATA}

We sampled the shares of Taiwan's small and mid-sized companies that were frequently traded in Taiwan Stock Exchange Corporation. The study period ranged from Q1 2010 to Q3 2019. All sampled companies executed share repurchases in 2016, thus, we used 2016 as a distinction and divided the study period into two intervals - before and after the announcement of share repurchase. Our analysis covers two time intervals: one is from Q1 2010 to Q4 2015 and the other from Q1 2016 to Q3 2019. After removing incomplete and outlier data, 249 observations remained. The data were extracted from the Taiwan Economic Journal databank. Table 1 illustrates the definition and measurement of the data. 
Table 1: Data Definition and Measurement-Taiwan Small and Mid-Sized Companies

\begin{tabular}{|c|c|c|c|}
\hline Notation & Variable & Measurement & Source \\
\hline$A R_{i,(t-1, t)}$ & $\begin{array}{l}\text { The Level of } \\
\text { Company } \\
\text { Abnormal } \\
\text { Returns }\end{array}$ & $\begin{array}{l}\text { Company abnormal returns, the } \\
\text { balance of period t deduct period } t-1\end{array}$ & TEJ \\
\hline$B S Z_{i, t}$ & Director Size & Number of directors on the board & TEJ \\
\hline$F N H D_{i, t}$ & $\begin{array}{l}\text { Shareholding } \\
\text { rate of the } \\
\text { foreign } \\
\text { institutions }\end{array}$ & $\begin{array}{l}\text { Fraction of foreign institutions } \\
\text { owned }\end{array}$ & TEJ \\
\hline $\operatorname{DIRHD}_{i, t}$ & $\begin{array}{l}\text { Shareholding } \\
\text { Rate of the } \\
\text { Directors }\end{array}$ & $\begin{array}{c}\text { Fraction of the Firm owned by the } \\
\text { Directors }\end{array}$ & TEJ \\
\hline$S T K P_{i, t}$ & $\begin{array}{c}\text { Share Prices } \\
\text { of the } \\
\text { company }\end{array}$ & $\begin{array}{l}\text { The market value of company, } \\
\text { which represents a company's } \\
\text { growth }\end{array}$ & TEJ \\
\hline$C R_{i, t}$ & $\begin{array}{l}\text { Current Ratio } \\
\text { of company }\end{array}$ & $\begin{array}{l}\text { The current assets divided by total } \\
\text { assets of company }\end{array}$ & TEJ \\
\hline$D R_{i, t}$ & $\begin{array}{l}\text { Debt Ratio of } \\
\text { company }\end{array}$ & $\begin{array}{l}\text { The total debts divided by total } \\
\text { assets of company }\end{array}$ & TEJ \\
\hline
\end{tabular}

\section{EMPIRICAL RESULTS}

This study uses Taiwan's small and mid-sized companies under NTD10 billion market capitalization to explore the impact of when a company first implements a strategy of share repurchase. In this section, we present and discuss the estimation results of the regression equation shown in Eq. (1). We began our analysis by testing the association of company abnormal returns scores for Taiwan's small and mid-sized companies with two variable groups: (1) corporate governance factors - director shareholding rate, foreign institution shareholding rate and board size, and (2) company-specific financial characteristics - share prices, current ratio and debt ratio. Tables 2 and 3 individually summarize the panel regression estimation results of two different intervals - before and after the announcement of share repurchase. Table 2 summarizes the estimation results before the announcement of share repurchase, during the time interval Q1 
International Journal of Social Science and Economic Research

ISSN: $2455-8834$

Volume: 05, Issue: 04 "April 2020"

2010 to Q4 2015. Table 3 summarizes the estimation results after the announcement of share repurchase, during the time interval Q1 2016 to Q3 2019. The Hausman test of two tables showed that the FEM provides the greatest explanatory power.

Table 2: Estimation Results of Panel Regression - Taiwan Small and Mid-Sized Companies

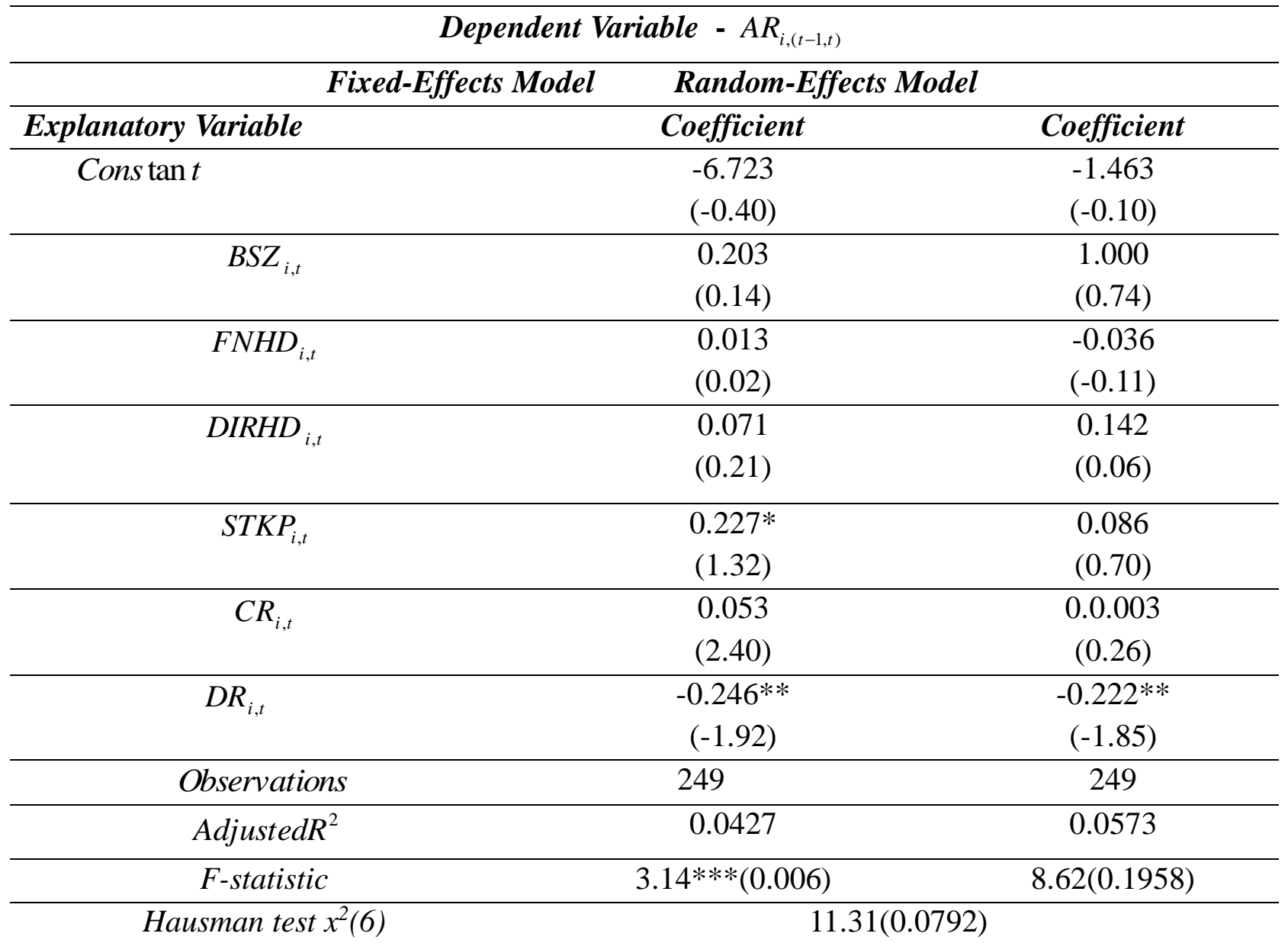

Notes: Dependent variable is company abnormal returns of Taiwan's small and mid-sized companies. Time period is Q1 2010 to Q4 2015. The testing results show that Fixed Effects Model (FEM) has the largest explanatory power. The figures in parentheses are $t$ statistics. *significant at $10 \%$ level; **significant at $5 \%$ level; ***significant at $1 \%$ level. 
International Journal of Social Science and Economic Research

ISSN: $2455-8834$

Volume: 05, Issue: 04 "April 2020"

Table 3: Estimation Results of Panel Regression - Taiwan Small and Mid-Sized Companies

\begin{tabular}{|c|c|c|}
\hline \multicolumn{3}{|c|}{ Dependent Variable $-A R_{i,(t-1, t)}$} \\
\hline \multicolumn{2}{|c|}{ Fixed-Effects Model $\quad$ Random-Eff } & \multirow[b]{2}{*}{ Coefficient } \\
\hline Explanatory Variable & Coefficient & \\
\hline \multirow{2}{*}{ Cons $\tan t$} & -1.319 & 4.097 \\
\hline & $(-0.23)$ & $(1.07)$ \\
\hline \multirow{2}{*}{$B S Z_{i, t}$} & -0.020 & $-0.109 * *$ \\
\hline & $(-0.25)$ & $(-1.82)$ \\
\hline \multirow[t]{2}{*}{$F N H D_{i, t}$} & $0.0001^{*}$ & 0.0028 \\
\hline & $(0.02)$ & $(0.50)$ \\
\hline \multirow[t]{2}{*}{$D_{\text {DIRHD }}$} & $0.169 *$ & 0.046 \\
\hline & $(1.34)$ & $(0.67)$ \\
\hline \multirow[t]{2}{*}{$S T K P_{i, t}$} & $0.229 * * *$ & $-0.042^{*}$ \\
\hline & $(4.91)$ & $(-1.32)$ \\
\hline \multirow[t]{2}{*}{$C R_{i, t}$} & $0.289^{* *}$ & 0.078 \\
\hline & $(2.62)$ & $(0.97)$ \\
\hline \multirow[t]{2}{*}{$D R_{i, t}$} & 0.195 & 0.191 \\
\hline & $(0.50)$ & $(0.51)$ \\
\hline Observations & 195 & 195 \\
\hline AdjustedR $^{2}$ & 0.0005 & 0.1913 \\
\hline$F$-statistic & $6.82 * * *(0.000)$ & $20.81(0.0020)$ \\
\hline Hausman test $x^{2}(6)$ & & \\
\hline
\end{tabular}

Notes: Dependent variable is company abnormal returns of Taiwan's small and mid-sized companies. Time period is Q1 2016 to Q3 2019. The testing results show that Fixed Effects Model (FEM) has the largest explanatory power. The figures in parentheses are $t$ statistics. *significant at $10 \%$ level; **significant at $5 \%$ level; ***significant at $1 \%$ level.

This study primarily examined the correlation of share repurchase, corporate governance and company operating performance. In examining the impact of director shareholding (DIRHD) on abnormal returns, we found a significantly positive result after the announcement of share repurchase - for execution year 2016 (Table 3). This indicates that after the share repurchase, when companies have higher director shareholding rates, board directors typically strive to strengthen monitoring and result in greater abnormal returns. We also found that after the share 
International Journal of Social Science and Economic Research

ISSN: $2455-8834$

Volume: 05, Issue: 04 "April 2020"

repurchase announcement, director shareholding displays a more significant and positive influence on $A R$ than before the announcement. Before 2016, the DIRHD variable is insignificant. This implies that after the announcement, corporate governance factors display higher monitoring effects, thus conveying more new information to the financial market, and increasing AR. As noted by Agrawal and Mandelker (1990), the shareholding of board directors promotes a crucial monitoring role, thus giving rise to a positive effect on $A R$. This phenomenon suggests that when board directors are more aligned with shareholders, they may decrease information asymmetry and agency costs, leading to increased $A R$. Meanwhile, it also indicates when Taiwan's small and mid-sized companies perform share repurchases, the main reason is likely to address undervaluation and the agency problem.

The foreign institution shareholding variable also exhibits a significantly positive influence on abnormal returns after the execution year (2016), while the influence before 2016 is insignificant. As shown in Table 2 and Table 3, the empirical results illustrate that after the announcement of share repurchase, foreign institution shareholding also displays a higher monitoring effect, thus increasing abnormal returns. By repurchasing shares, companies may improve the corporate governance structure to reform companies, such as through a higher-level of director shareholding and foreign institutions shareholding, to take an active role in the governance system, and induce better post-announcement operating performance.

By comparing companies performing share repurchase with companies that did not, Han, Lee and Song (2014) showed that companies usually possess higher agency costs before the announcement, however after the announcement, Taiwan's small and mid-sized companies may use corporate governance factors - director shareholding and foreign institution shareholding to reduce a company's agency problems, usually leading to a post-announcement performance increase. Our evidence also supports the monitoring effect of corporate governance systems. This corporate governance mechanism is effective and showed consistent and positive results in Taiwan's small and mid-sized companies.

In the aspect of financial factors, STKP (company's share prices) indicates the growth and market value of a company. Our empirical results show that the coefficient of STKP has a significantly positive relationship with abnormal returns, both before and after the announcement year. The effect was especially pronounced after the execution year. We found that the empirical result of Table 3 is more significant than Table 2, as shown by a larger coefficient $(0.229>0.227)$. This result implies that the market has a positive reaction to the share repurchase announcement, and company share prices go up. Wang (2016) discovered that when a company performs a share repurchase especially after the announcement, share prices will increase along with the company's EPS. This situation indicates that the shareholders have an optimistic view of the 


\section{International Journal of Social Science and Economic Research}

ISSN: $2455-8834$

Volume: 05, Issue: 04 "April 2020"

company's future.

Our results showed that the debt ratio did not have a significant effect after the announcement compared to before the announcement. Before 2016 (Table 2), the evidence showed a significant negative debt ratio, which probably indicates that during the period 2010-2015, companies had a higher degree of agency problems leading to a higher debt ratio. Thus, companies tend to perform share repurchases to increase share prices. After the execution year, the debt ratio does not have as significant an effect as before the announcement.

\section{CONCLUSION}

Companies may use share repurchase strategy to adjust to more optimal capital structure, thus promoting its whole value. This study uses Taiwan's small and mid-sized companies who are performing their first share repurchase to study the impact of corporate governance factors and company financial characteristics on company abnormal returns, comparing the difference before and after the announcement. We note the following findings.

The motivation to share repurchase seems to be to signal company undervaluation. Before the announcement, companies usually have a higher debt ratio (indicating higher agency costs) and lower operating performance, thus sending out a signal of poor performance. From the empirical results of this study - before the announcement, debt ratio (agency cost) has a significant negative effect on the company's $A R$. This highlights that company undervaluation and agency problems are correlated. However, we discovered that after the announcement of share repurchase, higher director ownership and foreign institution ownership has a significant positive effect on company abnormal returns. Meanwhile, the company's share prices, current ratio and post operating performance also go up. Director ownership as a corporate governance factor may decrease the frequency of share repurchases. If the company has more treasury shares, the probability of frequent share repurchases will increase, which indicates large companies with good operating performance will not perform share repurchases frequently. As outside foreign institutions ownership increases, the probability of share repurchase will decrease. Further, Han, Lee and Song (2014) indicated that companies with frequent share repurchases have higher agency costs and lower operating performance, thus managers may use a share repurchase strategy to elevate and raise share prices to protect shareholders equity. When a company repurchases shares, they may sell treasure shares to employees when share prices are too low, or even cancel the shares, eventually driving the share prices up. A high degree of company agency problems and managers' abuse of information asymmetry will induce companies to increase share repurchase. Therefore, frequent share repurchases often correlates with the signal of poor share prices and performance. This situation may be improved with a good corporate governance 
International Journal of Social Science and Economic Research

ISSN: $2455-8834$

Volume: 05, Issue: 04 "April 2020"

mechanism. These findings support the monitoring effect from good corporate governance not only in a general company but also in a company that repurchased shares.

In addition, Almeida, Fos and Kronlund (2015) analyzed share repurchase policy and investment variables focusing on the motivation to repurchase shares. They found that the evidence exhibits negative $A R$ before the announcement, but positive $A R$ after the announcement. Our study has empirical results consistent with Almeida, Fos and Kronlund (2015). In the future, we also expect to know if the share prices increase after the announcement is a short-term or long-term reaction. This determination will require an extended period of post-announcement results to illustrate a clearer picture for public investors, top management and governmental policy-makers to develop appropriate policy.

\section{REFERENCES}

[1] Agrawal, A. and Mandelker, G. N., "Large shareholders and the monitoring of managers: The case of antitakeover charter amendments," Journal of Financial and Quantitative Analysis, vol.25, pp.143-161, 1990.

[2] Almeida, H., Fos, V. and Kronlund, M., "The Real effects of share repurchases," Journal of Financial Economics, vol.119, pp.168-185, 2015.

[3] Ang, J. S., Cole, R. A., and Lin, J. W., "Agency costs and ownership structure," Journal of Finance, vol.55, pp. 81-106, 2000.

[4] Dittmar, A. K., "Why do firms repurchase stock?" Journal of Business, vol.73, pp.331$355,2000$.

[5] Ginglinger, E., and L'her, J. F., “ Ownership structure and open market stock repurchases in France," European Journal of Finance, vol.12, pp.77-94, 2006.

[6] Grullon, G. and Michaely, R., "The information content of share repurchase programs," Journal of Finance, vol.59, pp.651-680, 2004.

[7] Han, S. H., Lee B. S., and Song M., "Frequent Stock Repurchases, False signaling, and Corporate Governance: Evidence from Korea," Corporate Governance: An International Review, vol. 22(6), pp. 482-500, 2014.

[8] Jagannathan, M. and Stephens, C., "Motives for multiple open-market repurchase programs," Financial Management, vol.32, pp.71-91, 2003. 
[9] Singh, M. and Davidson, W. N. III, “ Agency costs, ownership structure and corporate governance mechanisms," Journal of Banking and Finance, vol.27, pp.793-816, 2003.

[10] Vermaelen, T., "Common stock repurchases and market signaling: An empirical study," Journal of Financial Economics, vol.9, pp. 139-183, 1981.

[11] Wang K. C., "The effect of stock repurchase on stock returns and corporate performance," Master Dissertation, National Sun Yat-Sen University, 2016.

[12] Wu, R., "Does corporate governance quality lend credibility to open-market share repurchase announcement?" Corporate Governance: an International Review, vol.10, pp.490-508, 2012.

[13] Yook, K. C., "Long-run stock performance following stock repurchases," Quarterly Review of Economics and Finance, vol.50, pp.323-331, 2010. 